\title{
Retinoblastoma Case: Shall We Get A Paramagnetic Trend in Chemotherapy?
}

\author{
Alrxander A Bukhvostov, Anton S Dvornikov, Kirill V Ermakov and Dimitry A Kuznetsov*
}

Interfaculty Cellular and Molecular Oncology Research Group, School of Medicine, N. I. Pirogoff Russian National Research Medical University, 1 Ostrovityanov St., Moscow 119997, Russian Federation

${ }^{*}$ Corresponding author: Dimitry A. Kuznetsov, Interfaculty Cellular and Molecular Oncology Research Group, School of Medicine, N. I. Pirogoff Russian National Research Medical University, 1 Ostrovityanov St., Moscow 119997, Russian Federation, Tel: +7(925)937-3717; E-mail: kuznano@mail.ru

Received: April 21, 2017; Accepted: September 30, 2017; Published: October 11, 2017

Citation: Bukhvostov AA, Dvornikov AS, Ermakov KV, Kuznetsov DA (2017) Retinoblastoma Case: Shall We Get A Paramagnetic Trend in Chemotherapy? Arch Can Res Vol.5:No.4:158.

\section{Abstract}

We have performed our study on a NEN-treated RB cell culture derived from a real clinical autopsy material. 3.5year-old male donor has died of a massive complex abdominal trauma being previously RB-diagnosed with NMR and ultrasound tests, tumor located behind the eye globe equator line.

This is a first report ever on magnetic isotope effects of metal ions to cause the clear anti-cancer consequences in retinoblastoma cells by depriving them of the DNA repair capabilities. Both molecular mechanism of phenomenon and its possible meaning for retinoblastoma chemotherapy are presented here.

Keywords: Retinoblastoma; Paramagnetics; Chemotherapy

Abbreviations: RB: Retinoblastoma; DNApolB: DNA Polymerases Beta; MIE: Magnetic Isotope Effect; NEN: NEthyl-Melamide; NMR: Nuclear Magnetic Resonance; AML: Acute Myeloblast Leukemia.

\section{Introduction}

DNA Polymerases Beta (DNApolB, EC 2.7.7.7) are the key players in DNA repair scenario which makes them critical for malignant cell survival mechanism $[1,2]$. This also makes them legitimate targets for pharmacologically promising inhibitors [3] including paramagnetic (magnetic, in brief) bivalent metal ions, $\left(\mathrm{nMe}^{2+}\right)[4,5]$. Being capable to promote the magnetic isotope effects (MIE) in vivo and in vitro these ions could be employed to "turn off" DNApolB to limit the tumor growth $[6,7]$. Particularly, retinoblastoma (RB) is an appropriate object for such an impact due to the DNA repair engaging paths of epigenetic control revealed in this peculiar cancer [8]. To find out the in situ degree and validity of an impact like that, all cellular DNA polymerase species except for the beta ones (i.e., alpha, gamma and delta) might be selectively suppressed by
$\mathrm{N}$-ethyl-melamide (NEM) [9]. Investigating a potential of the $\left[\mathrm{nMe}^{2+}\right] \mathrm{MIE}-$ Chemotherapeutic approach.

\section{Case Presentation}

We have performed our study on a NEN-treated RB cell culture derived from a real clinical autopsy material. Some prophetic predictions regarding a therapeutic validity of epigenic DNA expression control in retinoblastoma (RB) has been publicized lately [8] and then confirmed considering the cancer DNA repair machinery as a target once its key part, DNA Polymerase Beta, overexpressed [2,7]. However, being predominantly based on experiments with RB cell lines like WERI-RB or Y79, this statement still may be treated as "immature" since the in vivo operating neuro-immune and neuro-endocrine paths are no doubt capable of making an impact on intracellular epigenetic environment. This means a necessity to verify the DNApolB related findings on a donor derived RB specimen. To fit this requirement, we have investigated both cell viability and the DNApolB function in a departed patient's RB cells in culture subjected to such DNApolB effectors as the paramagnetic stable metal isotopes.

A unilateral solitary $12.5 \mathrm{~mm} \mathrm{RB} \mathrm{(2A)} \mathrm{was} \mathrm{taken} \mathrm{to} \mathrm{prepare}$ and maintain this cancer cell culture as described in method for preparation of culture of human retina pigment epithelium cells [10]. 3.5 year old male donor has died of a massive complex abdominal trauma being previously RB-diagnosed with NMR and ultrasound tests, tumor located behind the eye globe equator line. $8 \mathrm{hrs}$ after the death, an eye was enucleated. A verified parental assent was taken as ordered by an Article 47 of the Russian Federal Law \# 323-FZ of 01.01.2017. Both routine confocal images and MTT data were applied to elucidate the viability of cells estimating the LC50 $(\mu \mathrm{g} / \mathrm{mL})$ values $[10,11]$. In $12 \mathrm{hrs} 37^{\circ} \mathrm{C}$ pre-incubated samples, NEN was added to $0.5 \mathrm{mM}$ for a complete suppression of all but Beta DNA Polymerase species [5]. 6 hrs after, the nascent DNA were labeled with [Methyl-1,2-3H] dTTP, $180-220 \mathrm{Ci}$ / $\mathrm{mmol}, 100 \mu \mathrm{Ci}$ per $1.0 \mathrm{~mL}$ culture. The resulting NEN-resistant ([3H]DNA cpm/mg protein) values were considered as the in situ DNApolB specific activity patterns according to Bukhvostov AA et al. [5,9]. All protein measurements, DNA extraction, DNApolB catalytic activity determination, standard DNA $1.8 \%$ agarose gel electrophoresis followed by the DNA chain size 
range estimate were carried out as described in analytical techniques in biochemistry and molecular biology [12] and modified it.

Table 1 DNA repair key enzyme and cell viability affected by stable metal isotopes in retinoblastoma ex vivo culture.

\begin{tabular}{|c|c|c|c|c|}
\hline \multicolumn{2}{|l|}{ Isotopes } & \multicolumn{2}{|c|}{ *DNApolB Expression Patterns } & \multirow{3}{*}{$\begin{array}{l}{ }^{*} \mathrm{LC} 50, \mu \mathrm{g} / \mathrm{mL} \\
8.4\end{array}$} \\
\hline & & \multirow{2}{*}{$\begin{array}{l}\text { Catalytic activity, } \\
\text { [3H]DNA cpm/mg protein } \\
14,810\end{array}$} & \multirow{2}{*}{$\begin{array}{l}\text { DNA chain } \\
\text { size range, } \mathbf{n}\end{array}$} & \\
\hline Magnetic & {$\left[{ }^{25} \mathrm{Mg}^{2+}\right], 15.0 \mu \mathrm{g} / \mathrm{mL}$} & & & \\
\hline & {$\left[{ }^{43} \mathrm{Ca}^{2+}\right], 15.0 \mu \mathrm{g} / \mathrm{mL}$} & 20,330 & $180-220$ & 5.33 \\
\hline & {$\left[{ }^{67} \mathrm{Zn}^{2+}\right], 15.0 \mu \mathrm{g} / \mathrm{mL}$} & 17,086 & $190-230$ & 17.85 \\
\hline \multirow[t]{3}{*}{ Non-magnetic } & {$\left[{ }^{24} \mathrm{Mg}^{2+}\right], 15.0 \mu \mathrm{g} / \mathrm{mL}$} & 42,660 & $270-320$ & 103.2 \\
\hline & {$\left[{ }^{40} \mathrm{Ca}^{2+}\right], 15.0 \mu \mathrm{g} / \mathrm{mL}$} & 51,345 & $270-320$ & 166.42 \\
\hline & {$\left[{ }^{64} \mathrm{Zn}^{2+}\right], 15.0 \mu \mathrm{g} / \mathrm{mL}$} & 48,044 & $280-310$ & 197.86 \\
\hline
\end{tabular}

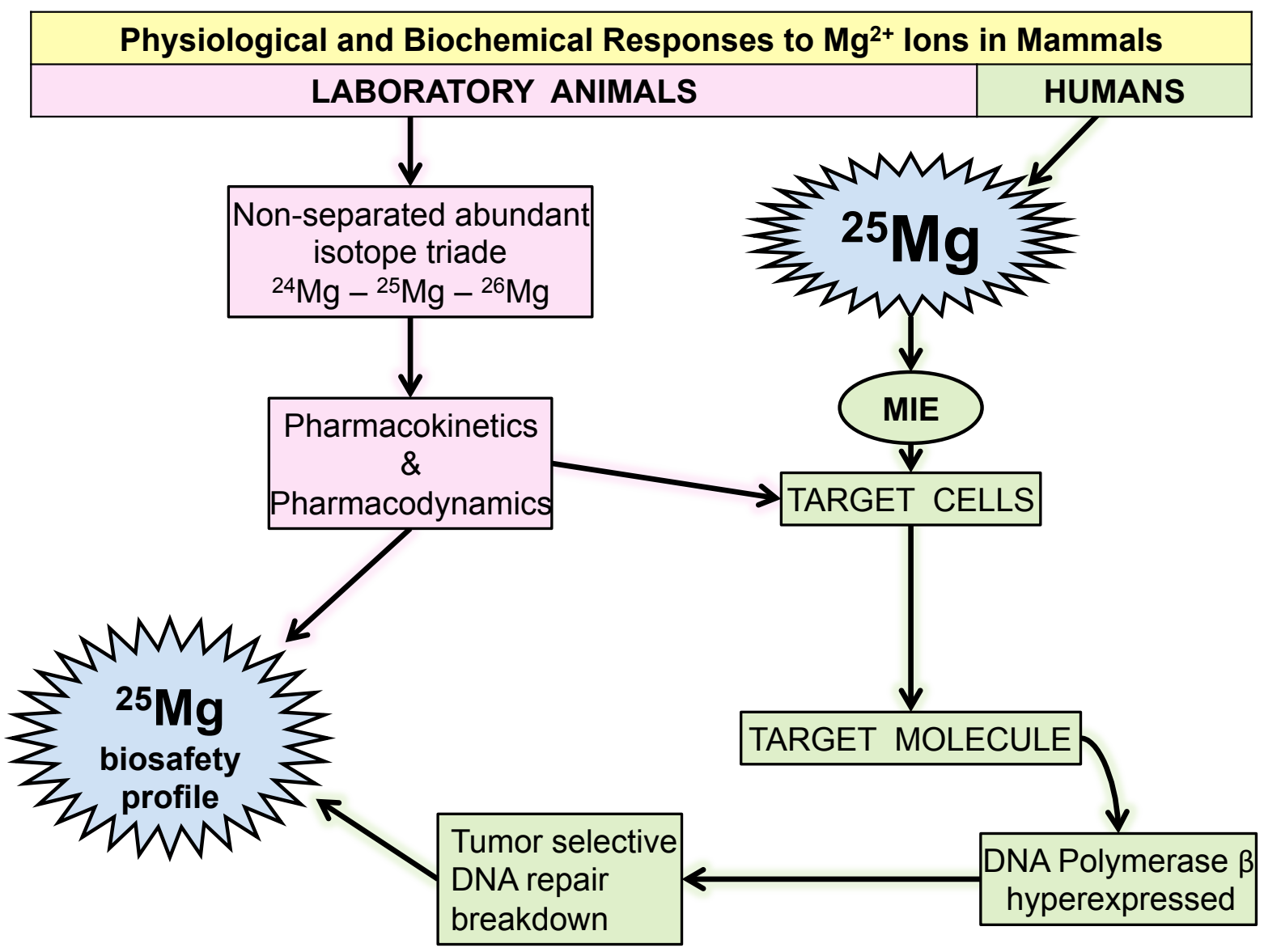

Figure 1 An algorithm for the magnetic isotope effect based preclinical trial research program.

The results listed in Table 1 shows that the RB cells are extremely sensitive to all three MIE-promoters $\left({ }^{25} \mathrm{Mg}^{2+},{ }^{43} \mathrm{Ca}^{2+}\right.$, ${ }^{67} \mathrm{Zn}^{2+}$ ) leading to a sharp increase of the cell mortality values which is likely relates to a marked DNApolB functioning breakdown. Noteworthy, a significant MIE-provoked shortening of the DNA fragments processed, by at least $20 \%$ to $25 \%$ in length, is also occurred (Table 1 ). This itself is about to deprive the cell of its usual DNA repair capabilities $[1,2,8]$ which is a reason to expect the tumor growth to get limited $[3,9]$. Thus, the MIE-dependent formation of these "size 
invalid", DNA repair insufficient, DNA sequences means an entirely new element in paramagnetic anti-cancer paradigm.

The applied medicinal significance of these data looks promising due to the followings: (a) the MIE ion-radical mode [4-7] does not allow the most members of DNA Polymerases diversity $(\alpha, \gamma, \delta)$ to get operated this way since the electron transfer distances in their catalytic sites are too long to make a "magnet" manifesting its MIE [1,3,5]; while (b) DNApolB is a perfect target for MIE-ions considering this enzyme active site 3D-structure $[4,7]$. Besides, (c) the above specified "magnets" were proven of being the substantial subjects for a cancer targeted delivery conducted with the low-toxic amphiphilic nanocationites [5,11]. Our ex vivo RB culture provides an advantage compared to the RB standard cell lines like WERI or Y79 for a whole body immune and endocrine systems are capable of making an unpredictable impact on epigenetic status of cancer. So the paramagnetic modulators of a DNApolB function deserves to get incorporated into retinoblastoma chemotherapy strategies.

\section{Discussion}

Thus, a preclinical test step for $25 \mathrm{Mg}^{2+}$ - MIE has been confirmed lately to complete the $A M L$ related arsenal of medicinal isotopes with the Magnesium-25 enriched, so to say "easy-to-permit", Mg-containing officinal drug forms [9]. In this case, a mode of the isotope anti-tumor action, caused by deprivation of the AML-specific DNA repair capabilities, has unambiguously determined by a number of circumstances including an MIE-allowing structural uniqueness of the DNA Polymerase Beta [4,5], hyperexpression of this target enzyme in AML [4] and by the ion-radical manner of the $25 \mathrm{Mg}^{2+}$ induced dysfunction of the tartget [2-5]. Considering the routine magnesium pharmacology profile, there is nothing obscure about the resulted Magnesium-25 safety profile too. Therefore, this translational research program does not require a full-scale safety doubting testing once the algorithm proposed is engaged (Figure 1).

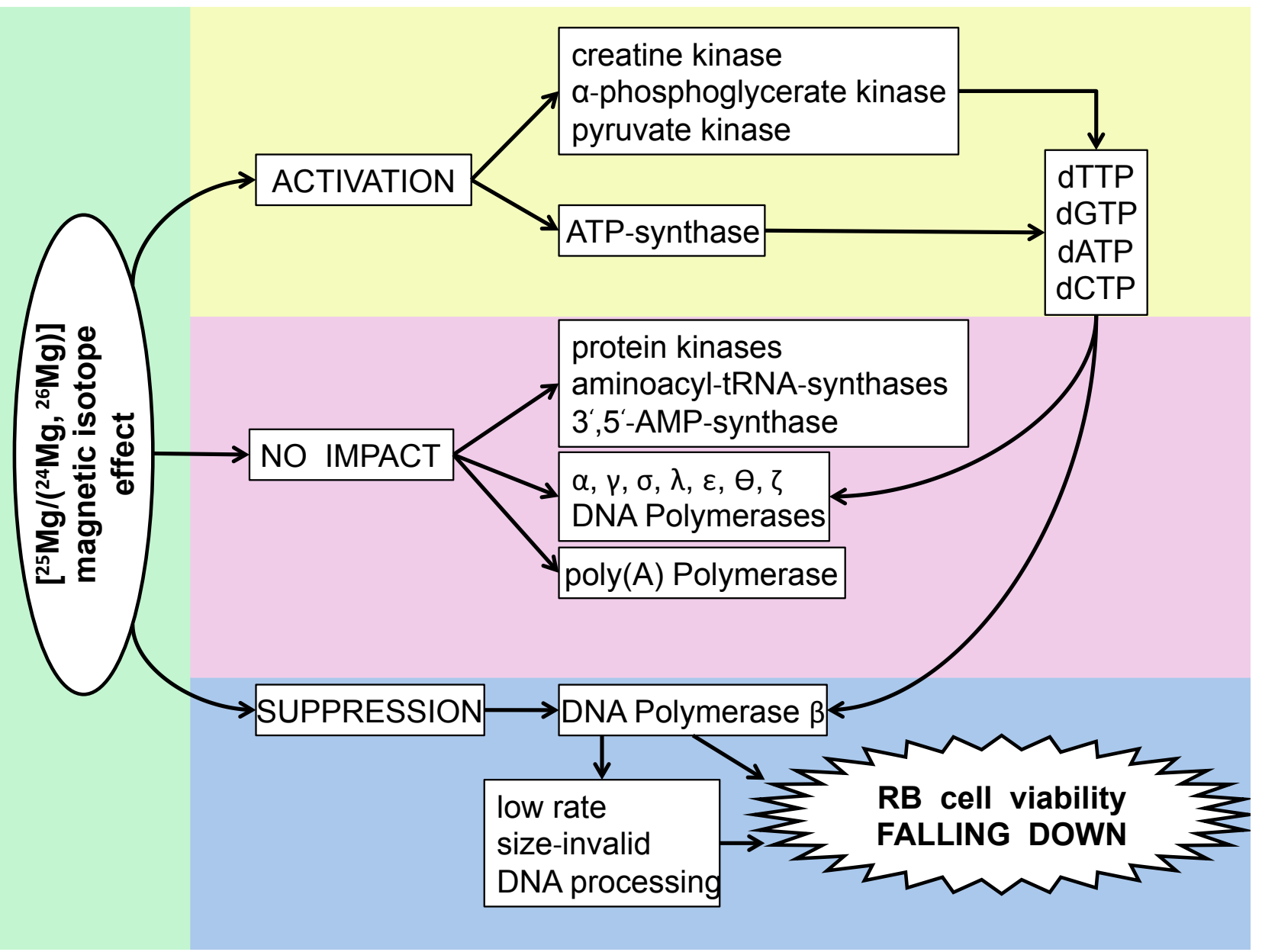

Figure 2 Magnesium magnetic isotope effects in human retinoblastoma cells as a background for anti-tumor activities.

\section{Conclusion}

There is no reason not to extrapolate this algorithm onto any other MIE-sensitive tumor chemotherapy including a novel RB treatment strategy $[2,8]$. To support this statement, a variable data on $25 \mathrm{Mg}^{2+}$ - MIE expression in RB cells might be taken into account $[1-3,8,10]$ (Figure 2). All these data, along with our original results presented here (Table 1 and Figure 1) are no doubt in a favor to a remarkable pharmacological 
potential of bivalent metal paramagnetics as the safe- $n$ efficient anti-retinoblastoma agents.

\section{References}

1. Ji S (2012) Molecular theory of the living cell: Concepts, molecular mechanisms, and biomedical applications. Springer Science \& Business Media.

2. Bozic I, Nowak MA (2017) Resisting resistance. Annu Rev of Cancer Biol 1: 203-221.

3. Martin S, McCabe N, Mullarkey M, Gummings R, Burgess DJ, et al. (2010) DNA polymerases as potential therapeutic targets in cancers. Cancer Cell 17: 235-248.

4. Buchachenko AL, Orlov AP, Kuznetsov DA, Breslavskaya NN (2013) Magnetic isotope and magnetic field effects on the DNA synthesis. Nucleic Acids Res 41: 8300-8307.

5. Bukhvostov AA, Napolov JK, Buchachenko AL, Kuznetsov DA (2014) A new platform for anti-cancer experimental pharmacology: the DNA repair enzyme affected. $\mathrm{Br} J$ Pharmacol 5: 35- 41.

6. Buchachenko AL (2016) Why magnetic and electromagnetic effects on biology are ambiguous and contradictory? Bioelectromagnetics 37: 1-13.
7. Buchachenko AL, Lawler RC (2017) New possibilities in magnetic control of chemical and biochemical reactions. Acc Chem Res 50: 877-884.

8. Zhang J, Benavente CA, McEvoy J, Flores-Otero J, Ding L, et al. (2012) A novel retinoblastoma therapy from genomic and epigenic analyses. Nature 48: 329-334.

9. Bukhvostov AA, Shatalov OA, Orlov AP, Kuznetsov DA (2013) An atypical DNA polymerase beta overexpressed in human AML/ HL-60 malignant cells. J Cancer Sci Thera 5: 94-99.

10. Kuznetsova AV, Milyushina LA, Likhvantseva VG, Alexandrova MA, Fedorenko AV (2011) Method for preparation of culture of human retina pigment epithelium cells. Russian Ophthalmology (in Russ) 11: 244-254

11. Orlova MA, Osipova EY, Roumiantsev SA (2012) Effect of 67Znnanoparticles on leukemic cells and normal lymphocytes. $\mathrm{Br} J$ Med Medical Res 2: 21-30.

12. Katoh $\mathrm{R}$ (2011) Analytical techniques in biochemistry and molecular biology. Springer, Berlin-Heidelberg. 